\title{
A STUDY OF VOLATILITY IN THE STOCK MARKET
}

\author{
Darsh kachhara \\ $2^{\mathrm{Nd}}$ Year Student, Sarla Anil Modi School Of Economics, NMIMS Mumbai \\ Mentor: Professor Rohit Muraleedharan
}

DOI: 10.46609/IJSSER.2020.v05i09.022 URL: https://doi.org/10.46609/IJSSER.2020.v05i09.022

\begin{abstract}
Volatility is nothing but a behvaioural change brought by investors as their perception of market keeps changing second by second due to various reasons other than the ones documented in the above Literature review. All over the world stock markets function in a similar manner but it's the investors with unknown rationality which decide the fate of the market indexes. Such wholesome changes in oil prices, political instability form the essescence of world supply chain irrespective of which country is involved. It is general idea in the market that financial exchanges are proficient and costs mirror all accessible data. There is broad research writing accessible to see whether securities exchanges are effective or not.
\end{abstract}

Keywords: Volatility, BSE, Stock Market, NSE, Index

\section{INTRODUCTION}

Stock market is a platform where shares of listed companies get traded/exchanged. The institute which helps buyers and sellers perform such activity is called a stock exchange. Inclusion of derivative products for trade increased the volatility and hence increased the participants in the market. Political and economic conditions depend on foreign relations and internal peace. Oil price is essential since its one of the most important resources for all sorts of energy. Elections in the largest democracy which will decide policies and market integration for the developed countries would also make investors all around the world interested. Similarly policy announcements, dollar currency and market anomalies have a effect on investor returns and market volatility.

\section{STOCK MARKET EFFICIENCY}

It is general idea in the market that financial exchanges are proficient and costs mirror all accessible data. There is broad research writing accessible to see whether securities exchanges are effective or not. A few academicians accept that securities exchange is frail productive 


\section{International Journal of Social Science and Economic Research}

ISSN: $2455-8834$

Volume:05, Issue:09 "September 2020"

(Cootner,1962; Fama, 19652; Kendall, 19533; Granger and Morgenstern, 1970). While some others have conviction that securities exchanges are not feeble effective (Chaudhary1991; Ranganatham and Subramanian, 1993).Efficiency of financial exchange has its suggestions for the entire economy and monetary advancement of any nation. As, on the off chance that financial exchange is sufficiently proficient, at that point there is no need of government obstruction in the market developments. As, if stock market is efficient enough then there is no need of government interference in the market movements. But, on the other side, in an inefficient market investor would like to take the benefit of extra ordinary information available to them. There are three forms of market efficiency i.e. strong form, semi strong and weak form efficiency have different consequences as far as excess returns are concerned. It is general notion in the market that stock markets are efficient and prices reflect all available information.

\section{VOLATILITY}

Volatility is a statistical measure of the dispersion of returns for a given security or market index. In most cases, the higher the volatility, the riskier the security. Volatility is often measured as either the standard deviation or variance between returns from that same security or market index. In India, the VIX index is considered an important element when it comes to gauging on volatility, it given the name of a "fear estimator" by Dalal Street. India VIX is a volatility index computed by NSE based on the order book of NIFTY Options. For this, the best bid-ask quotes of near and next-month NIFTY options contracts which are traded on the F\&O segment of NSE are used. India VIX indicates the investor's perception of the market's volatility in the near term i.e. it depicts the expected market volatility over the next 30 calendar days. Higher the India VIX values, higher the expected volatility and vice- versa. The Chicago Board of Options Exchange (CBOE) was the first to introduce the volatility index for the US markets in 1993 based on S\&P 100 Index option prices. In 2003, the methodology was revised and the new volatility index was based on S\&P 500 Index options. (NSE, India).

\section{SHORTING}

Speculators although aren't welcomed by many financial economist are one of the reasons for panic selling. Bubble, political instability, governance issue in the company causes bears to speculate and hence bet against the market. F\&O market is one of the most liquid market in India and is responsible for such prompt corrective action.

\section{CURRENT SCENARIO}

The richest investor in the financial market, Mr buffet said "If you stick around long enough, you'll see everything in markets. And it may have taken me to 89 years of age to throw this one into the experience, but the markets, if you have to be open second by second, they react to news 
International Journal of Social Science and Economic Research

ISSN: 2455-8834

Volume:05, Issue:09 "September 2020"

in a big time way."( Warren Buffett reacts to the stock market rout, oil crash amid the coronavirus outbreak, yahoo finance 2020 )

Market all over the world came tumbling down to a 3 to 4 year low. S\&P 500 had a free fall worse than it had during the global recession , 2008. The coronavirus didn't indeed infect the financial market and the corporate supply chain of the entire world. Panic selling is one of the important reasons why the VIX index in India rose to its 12 year high at $75 \%$. It wasn't any technical view or a fundamental mistake, it was news.

The oil industry was also hit midst this deadly pandemic due to political hostility between Saudi Arabia , Russia and United States Of America which caused the black gold to valued almost $80 \%$ lower at $\$ 28$ a barrel. This also caused a rise in the bearish outlook and the BSE Sensex hit the lower circuit for the first time since 2008 . Volatility and panic made few very wealthy and many bankrupt. It still one of the most essential variables of an open market as it hold the very essence of human trading.

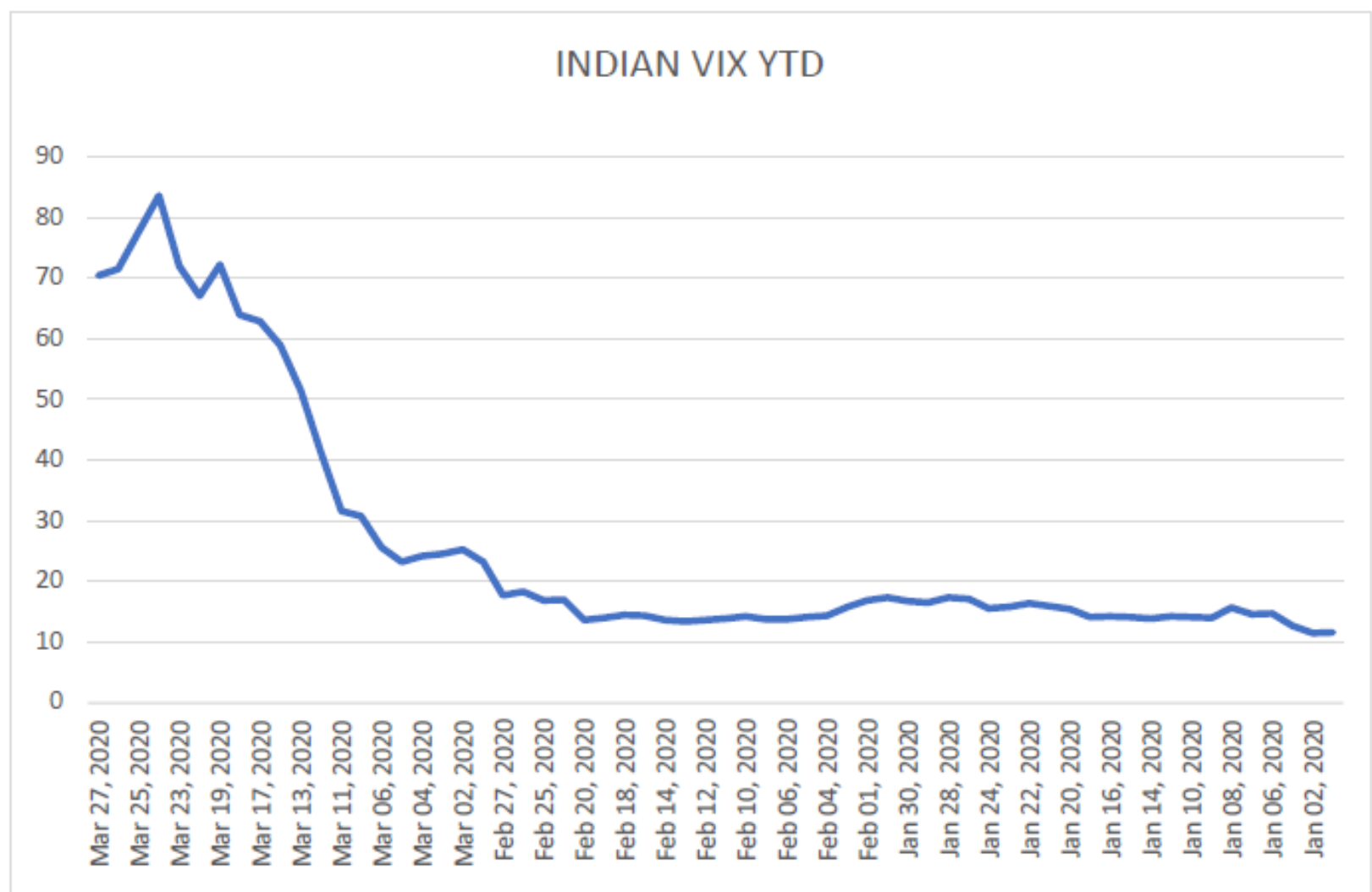


International Journal of Social Science and Economic Research

ISSN: 2455-8834

Volume:05, Issue:09 "September 2020"

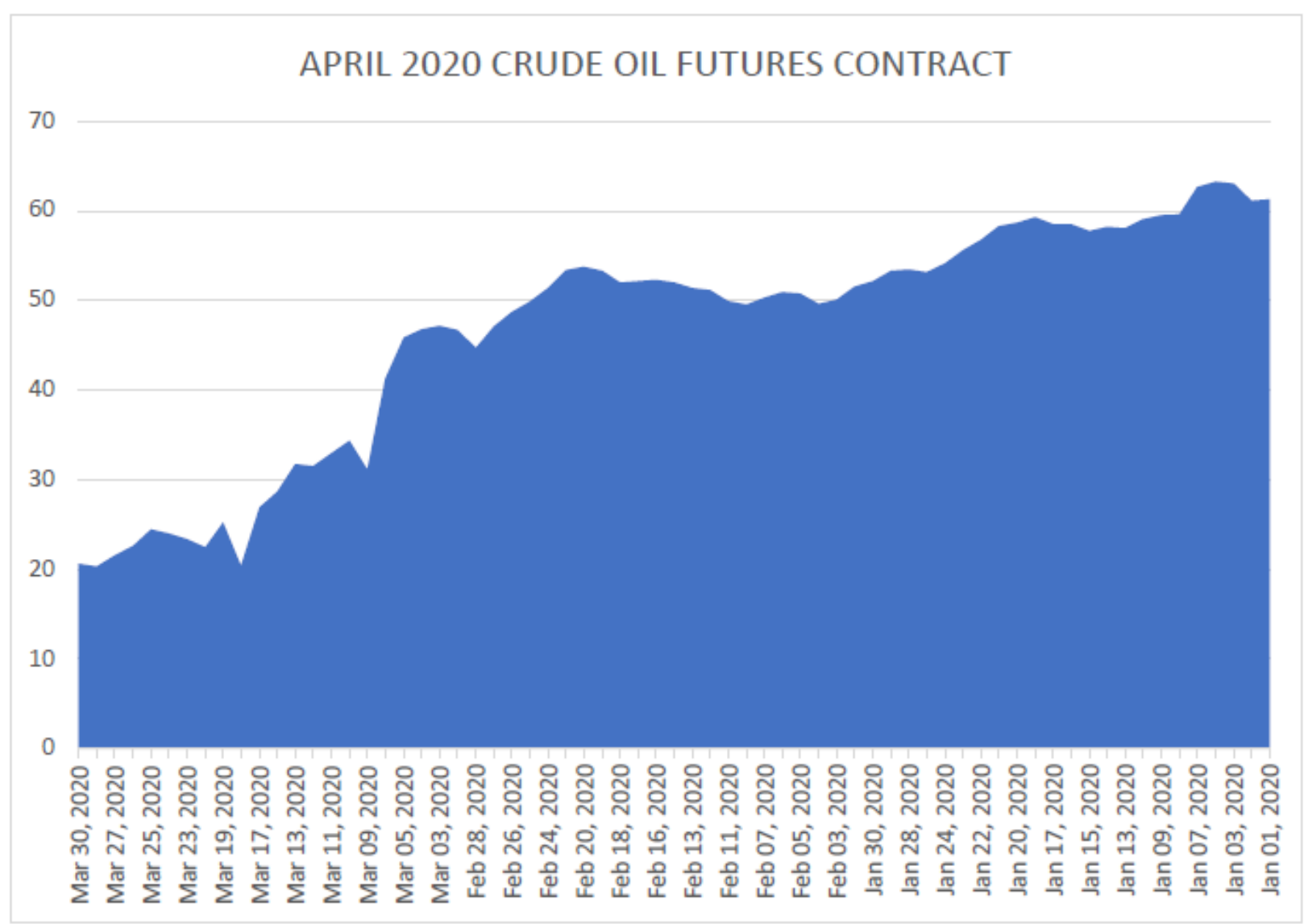


International Journal of Social Science and Economic Research

ISSN: 2455-8834

Volume:05, Issue:09 "September 2020"

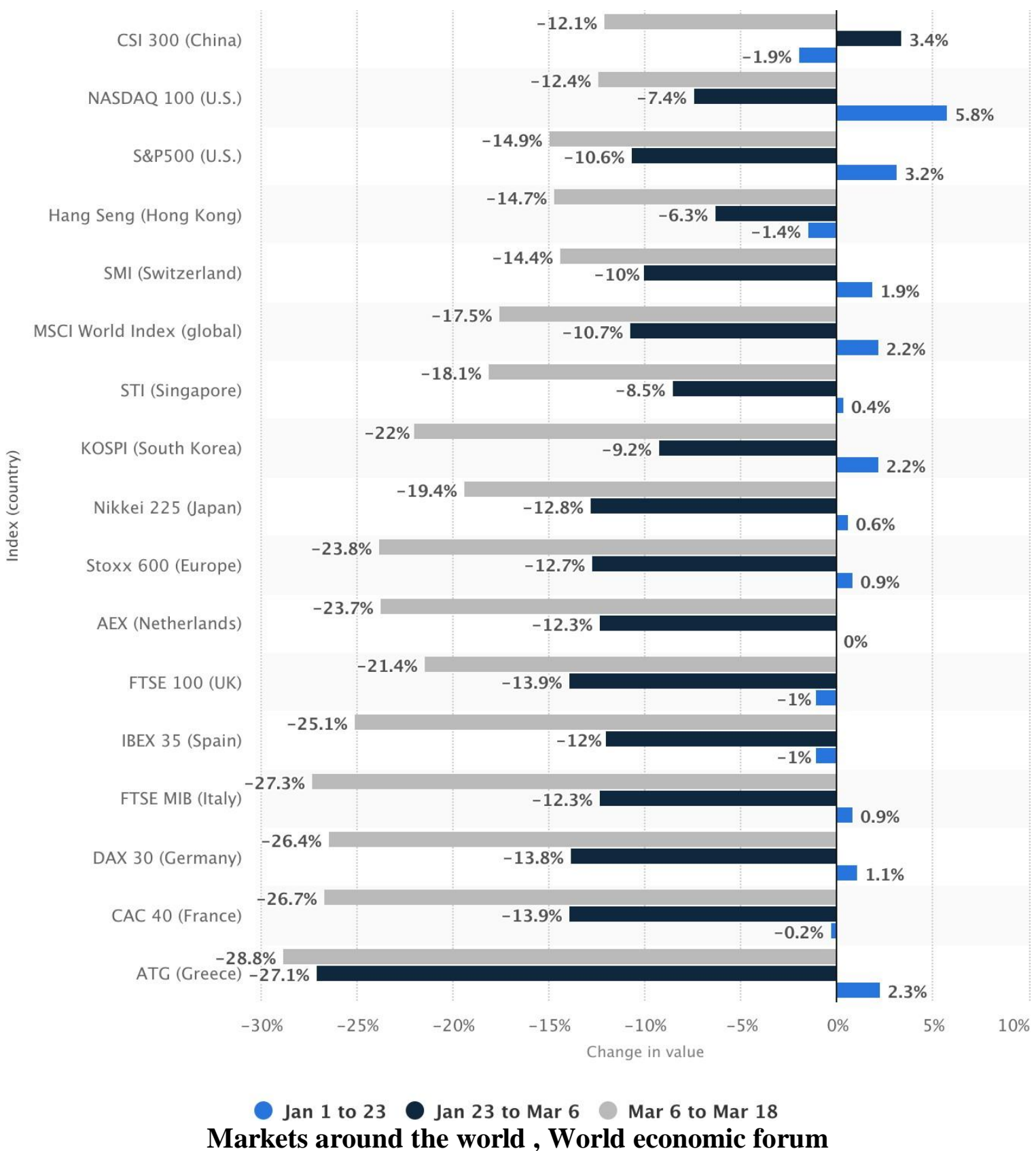

\section{LITERATURE REVIEW}

\section{OIL PRICES}

The paper by Jones and Kaul (1996) was among the first to uncover a negative connection between the oil costs and securities exchange returns. Also, Sadorsky (1999) presumes that oil value changes are significant determinants of financial exchange returns. Specifically, he shows 


\section{International Journal of Social Science and Economic Research}

ISSN: 2455-8834

Volume:05, Issue:09 "September 2020"

that securities exchanges react contrarily to a positive oil value change. Filis (2010), Chen (2009), Miller and Ratti (2009), Park and Ratti (2008), Driesprong et al. (2008) and Gjerde and Sættem (1999) second these discoveries by Sadorsky (1999) and Jones and Kaul (1996). Moreover, a strand of the writing recognizes the impacts of oil value stuns on securities exchange movement as per their starting point. Hamilton (2009a,b) and Kilian (2007a,b), specifically, recommend that various stuns in the oil showcase effectsly affect financial exchanges. Kilian (2009) give proof that the reaction of total stock profits varies depending for the reason for the oil value stun. Moreover, the (International Energy Agency 2006) (Nordhaus 2007) and (Blanchard and Gali Economies 2019, suggest that recent developments in investment, production, wage policies, and renewable resources tend to minimize the consequences of oil price changes in economies generally and stock resources tend to minimize the consequences of oil price changes in economies generally and stock markets particularly. Nevertheless, several studies show that the impact of oil price changes in the markets particularly. Nevertheless, several studies show that the impact of oil price changes in the national economies of oil-importing-countries can differ from those of oil-exporting countries.

Ciner (2001), using non-linear causality tests, provides empirical evidence that oil shocks significantly affect stock index returns in the US in a non-linear manner, and that the returns also have impacts on crude oil futures. Park and Ratti (2008) show that oil value stuns have a factually noteworthy effect on genuine stock returns contemporaneously and additionally inside the next month in the U.S. , 13 European nations over the period running from January 1986 to December 2005 and that Norway, as an oil exporter, shows a measurably altogether positive reaction of genuine stock comes back to an oil cost increment.

Stavros Degiannakis, George Filis , Renatas Kizys(2014) in their paper investigates the effects of oil price shocks on stock market volatility in Europe by focusing on three measures of volatility, i.e. the conditional, the realised and the implied volatility. In order to find the volatility figures they take daily data from January 1999 to December 2010 on aggregate European stock market indices. In particular, the stock market index used is Eurostoxx 50, which is Europe's leading blue chips stock market index and the data have been extracted from Datastream. The study examines the effects of three oil prices shocks (i.e., supply-side shock, aggregate demand shock and oil specific demand shock) on the stock markets using a structural VAR framework. The paper considers two volatility measures, namely the conditional volatility and the realised volatility, which measure the current stock market volatility. It also examine the effects of oil price shocks on implied volatility, as well, which is a forward- looking volatility measure. The end is that supply-side and oil specific demand shocks don't influence unpredictability, while, aggregate demand shocks impact instability at a critical level. This discovering holds for both the current-looking unpredictability and the suggested instability proportions of total securities 


\section{International Journal of Social Science and Economic Research}

ISSN: $2455-8834$

Volume:05, Issue:09 "September 2020"

exchange and mechanical area records. Furthermore, the two volatility models (short- and longmemory models) verify the SVAR results, proposing aggregate demand oil price shocks on volatility is negative and huge for all records and all measures.

Mathieu Gomes, Anissa Chaibi(2014) analyse most intuitive way through which oil prices can affect stock prices is by the channel of expected cash flows. Oil is a vital contribution to the creation of merchandise and ventures, and along these lines, an ascent in oil costs are probably going to expand creation costs, which thus will decrease edges, incomes and in this manner stock costs. Yet, oil costs can likewise influence stock valuations through the rate that is utilized to limit future incomes. Equity market data for this particular analysis is obtained from MSCI. The paper use a set of data consisting of twenty-one national aggregate stock market indices (Argentina, Bahrain, Bulgaria, Jordan, Kazakhstan, Kenya, Kuwait, Lebanon, Mauritius, Nigeria, Oman, Pakistan, Qatar, Romania, Saudi Arabia, Slovenia, Sri Lanka, Tunisia, United Arab Emirates, Ukraine, and Viet-Nam) and two broader stock indices (MSCI Frontier Markets and MSCI World), together with a measure of the world oil price (Brent). All data are at the weekly frequency and cover a five-year period ranging from February 8, 2008 to February 1, 2013, yielding a total of 261 observations. The paper uses weekly data because as suggested by Arouri and Nguyen (2010), they appear to be less noisy than daily data, while still capturing much of the information content of stock indices and oil prices.

The GARCH-type approach has received a special interest from almost all previous studies dealing with volatility modeling and forecasting of commodities prices. This paper analyzed the transmission of shocks and volatility between oil costs and Frontier financial exchanges. The statistical model includes a parameterization of the conditional variance-covariance of oil price changes and stock returns, specifically the bivariate $\operatorname{BEKK-GARCH}(1,1)$ model, which enables the analysis of spillovers in both returns and conditional variance. Results recommend noteworthy volatility cooperation among oil and some outskirts financial exchanges. Also, the spillover impact seems, by all accounts, to be bidirectional in numerous business sectors, which is a trademark that contrasts from what has been found for created securities exchanges where the transmission is normally unidirectional (from oil to financial exchanges). In any case, observational outcomes show that the spillovers run all the more frequently from oil to financial exchanges.

Korhan K. Gokmenoglu, Negar Fazlollahi(2015 )analyse The inter-relationship among money related and commodify markets is one of the most testing issues for financial specialists. The volatility in one market may influence the value list of the other market. Aim of this paper is to test whether, oil price, and oil price volatility (OVX) have significant effect on stock market price index (GSPC) or not. In order to carry out the task, due to the properties of the data, the ARDL co-integration approach has been used to check the long-run relationship among OVX and GVZ; 


\section{International Journal of Social Science and Economic Research}

ISSN: 2455-8834

Volume:05, Issue:09 "September 2020"

as proxies of oil and gold market volatility indexes; and S\&P500 market price index. Data for Euro Brent crude-oil spot price (in US dollars per share) were collected from the United States Energy Information Administration (U SEnergy, 2014). Market index based on the daily adjusted close price for S\&P500 (GSPC) was extracted from the Yahoo Finance website (S\&P500Dow, 2014). Volatility of oil (OVX) series, which have been available since 2008 were obtained from the CBOE official website (CBOE, 2014). The results imply that S\&P500 stock market price index (GSPC) converges to its long-run level by $1.2 \%$ speed of daily adjustment by contribution of oil and its volatilities. In the short- run volatilities of oil have no impact on S\&P500 stock market. Investors may not be willing to transfer their money to the other markets in the short-run, while in the long-run they react to the volatilities of oil prices. The discoveries likewise featured the short-run effect of changes in the oil cost on the financial exchange, taking into account that $10 \%$ of S\&P500 securities exchange has a place with vitality segment organizations (S\&P500 vitality, 2015). These organizations' stock costs would increment by any expansion in oil costs. The augmentation to this examination is to explore the effect of the referenced factors on every one of the parts in S\&P500 financial exchange, implies on industry stock, vitality stock, and transportation stock division, which leads to draw a very broad and valuable policy recommendation.

\section{ELECTIONS}

As India is the most populist democratic state, we consider literature review on its markets regarding volatility and General elections of the lower house of the country. Political ideologies play an important role in risk modeling even for a long-term perspective. But the anomaly arrives due to an "election cycle" where during the election the market returns are above average and the time post-election the returns are below average (Ling-Chun Hung (2011)).

Kumar Deva B , Sophia Sharon and Jucunda Evelyn Maria(2015) discusses the impact of Lok Sabha elections on stock market. BSE SENSEX Index and Companies have been taken for the analysis. Event study has been conducted in this paper. The event is $16^{\text {th }}$ Lok Sabha election result date (16th may 2014). Twitter has been opted to conduct sentimental analysis of investors regarding the overall economic and political climate. Researchers have tried to capture the use of social media and its data in foreseeing occasions, for example, Tsunami, films achievement, political decision surveys results, etc. The companies selected were expected to fulfil the following criteria:

1) The companies should be listed in Bombay Stock Exchange (SENSEX)

2) The companies should have market data for $(-14,+14)$ days around the specified announcement 
3) The companies should be active in twitter. The tweets were collected manually for each company.

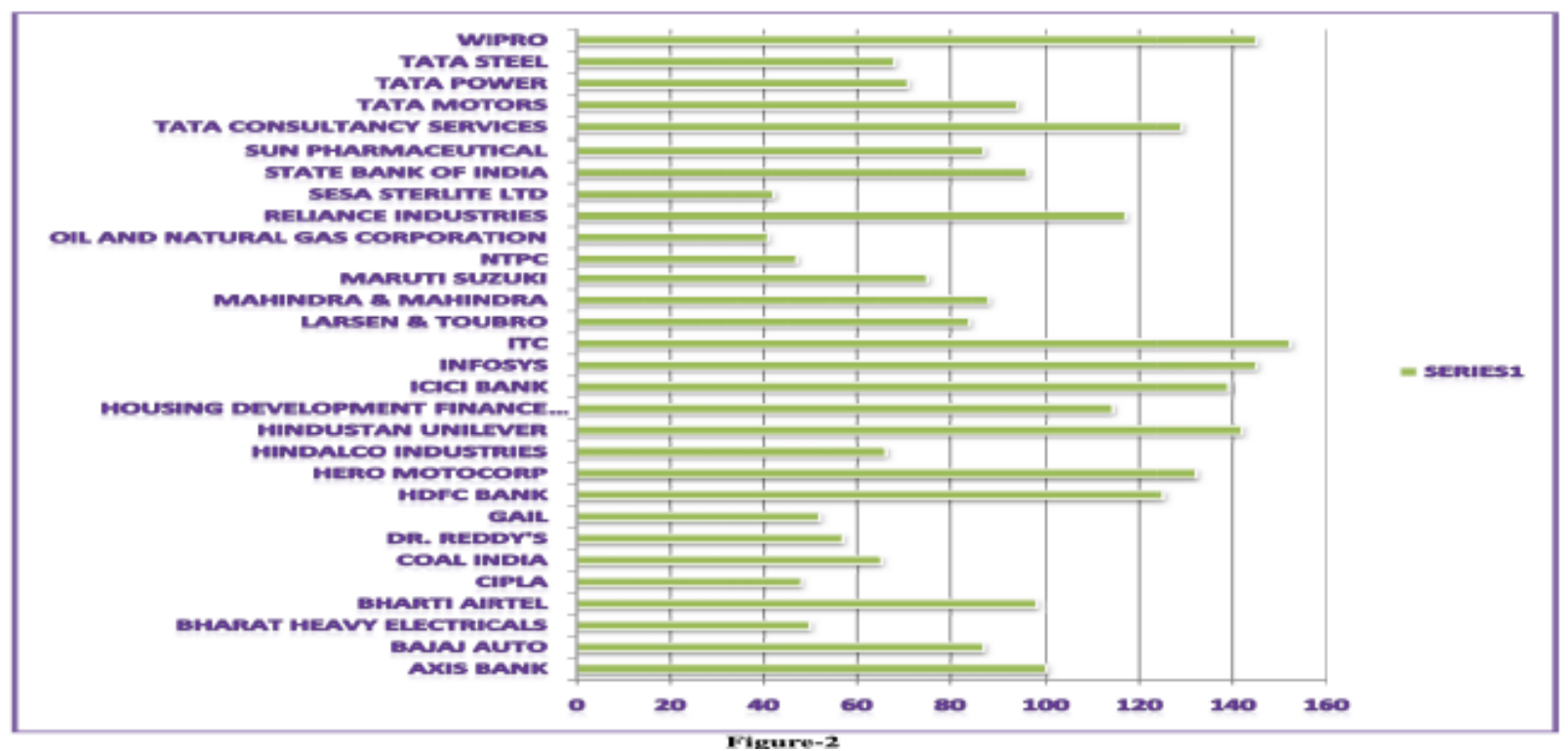

Number of tweets collected for each company

Tweets of each company are imported into R-Studio and registering and extremity of tweets for each organization. It at that point examinations the tweets Polarity and extremity utilizing different codes

Bullishness : $B_{t}=\ln \left(\frac{1+M_{t}^{\text {positive }}}{1+M_{t}^{\text {negative }}}\right)$

Agreement : $A_{t}=1-\sqrt{1-\frac{M_{t}^{\text {positive }}-M_{t}^{\text {negative }}}{M_{t}^{\text {positive }}+M_{t}^{\text {negative }}}}$

Positive\%= (total positive tweets)/ (total number of tweets) Negative $\%=$ (total negative tweets)/(total number of tweets) Joy\% $=$ (total joy tweets)/ (total number of tweets) $\mathrm{Sad} \%=$ (total sad tweets)/ (total number of tweets) Fear $\%=$ (total fear tweets)/ (total number of tweets) Anger \% $=($ total anger tweets)/ (total number of tweets)

The formula to determine the emotion of a tweet 
International Journal of Social Science and Economic Research

ISSN: 2455-8834

Volume:05, Issue:09 "September 2020"

\begin{tabular}{|c|c|}
\hline Variables & $\begin{array}{l}\text { Adjusted Cash Margin } \\
\text { Net Profie Margin }\end{array}$ \\
\hline $\operatorname{CAR}(-14,+14)$ & Return on I ong Term Fund \\
\hline Bullishness & $\begin{array}{l}\text { Return on Net Worth } \\
\text { Adiusted Return on Not Worth }\end{array}$ \\
\hline Agreement & $\begin{array}{l}\text { Return on Assets Exeluding } \\
\text { Revaluations }\end{array}$ \\
\hline Positive & $\begin{array}{c}\text { Net Interest Income / Total } \\
\text { Funds }\end{array}$ \\
\hline Negative & $\begin{array}{l}\text { Non Interest Income / Total } \\
\text { Funds }\end{array}$ \\
\hline Emotions (Joy, Sad, Surprise, & $\begin{array}{c}\text { Profit Before Provisions / } \\
\text { Total Funds }\end{array}$ \\
\hline Fear, Anger, Disgust) & Total Assets Turnover Ratios \\
\hline Face Value & Capital Adequacy Ratio \\
\hline Dividend Per Share & Total Dobt to Ownors Fund \\
\hline Operating Profit Per Share & $\begin{array}{c}\text { Financial Charges Coverage } \\
\text { Ratio Post Tax }\end{array}$ \\
\hline & $\begin{array}{c}\text { Dividend Payout Ratio Cash } \\
\text { Profit }\end{array}$ \\
\hline Net Operating Profit Per Share & Earning Rotontion Ratio \\
\hline Bonus in Equity Capital & Adjusted Cash Flow Times \\
\hline Interest Spread & $\begin{array}{c}\text { Earnings Por Share } \\
\text { Book Value }\end{array}$ \\
\hline
\end{tabular}

To finally examine the influence of twitter sentimental analysis on Cumulative Abnormal Returns, the multiple regression analysis is used. From the variable selected for the study only five variables shows that the companies are sensitive during event time period at $5 \%$ significance.

Profit and loss of the company is also affected by the change in the economic decision. he organizations in the private or open front likewise impact the unusual additions. The outcome shows that all the organization are response is delicate during the market changes and occasion additionally triggers the business sectors into different changes. This examination is a huge connection between Lok Sabha and financial exchange. There is a positive response showcase during the political race time. Organization's exogenous elements have been contributed determined occasion. Henceforth political decision is one of the market vacillations.

Savita ,A.Ramesh(2015) analyses the share price performance around National elections in India during the 2014 general elections. Because of progress in the market estimation, the stock costs respond to the adjustments in the Government. The paper research's investors' profits around national races for BSE SENSEX. 


\section{International Journal of Social Science and Economic Research}

ISSN: $2455-8834$

Volume:05, Issue:09 "September 2020"

The paper talks about the importance of the depth analysis into return volatility surrounding the market, First, the uncertainty about the election announcement has important ramifications for risk-averse investors. Earlier research indicated that investors are usually not diversified internationally and have a string home bias (French and Poterba, 1991; Baxter and Jermann, 1997). So they tend to hold more assets in their domestic boundaries which means the political risk will not be adjusted for in their portfolios. Second, any market-wide changes in light of political decision stuns will prompt increment in the systematic volatility of all listed stocks. Therefore it is evident that when voters go for casting their ballots, option prices could increase around that time. This study takes the data of BSE Sensex 30 companies from time period May 2013 to June 2014. Stock prices have been observed over different event windows like (- 15, $+15),(-2,+2),(-15,-2),(+2,+15)$. Daily closing prices of stocks listed on the BSE Sensex index itself has been taken for analysis purpose. CMIE prowess database has been used for data collection purpose. We have used event study methodology to examine the short-term prices reaction around the event day. This methodology comprises of two steps: first we define the event, its announcement date, the estimation period and the event window period. In second step, abnormal returns are calculated using the parameters estimated from the model. Announcement date of election results has been taken as day " 0 ". The other days are expressed relative to the result announcement date. The estimation period for the study is the days before the occurrence of the event. And it does not overlap with the event window period. We have considered estimation period of $241(-267,-26)$ days as estimation window.

The positive returns can be observed 3-4 days before the announcement of the results. This can be attributed to the surveys released before the actual announcement of the results. A strong abnormal rise happens on the date of announcement of election results and the continuous rise in the stock returns continues for a number of days after the event of declaration of results.

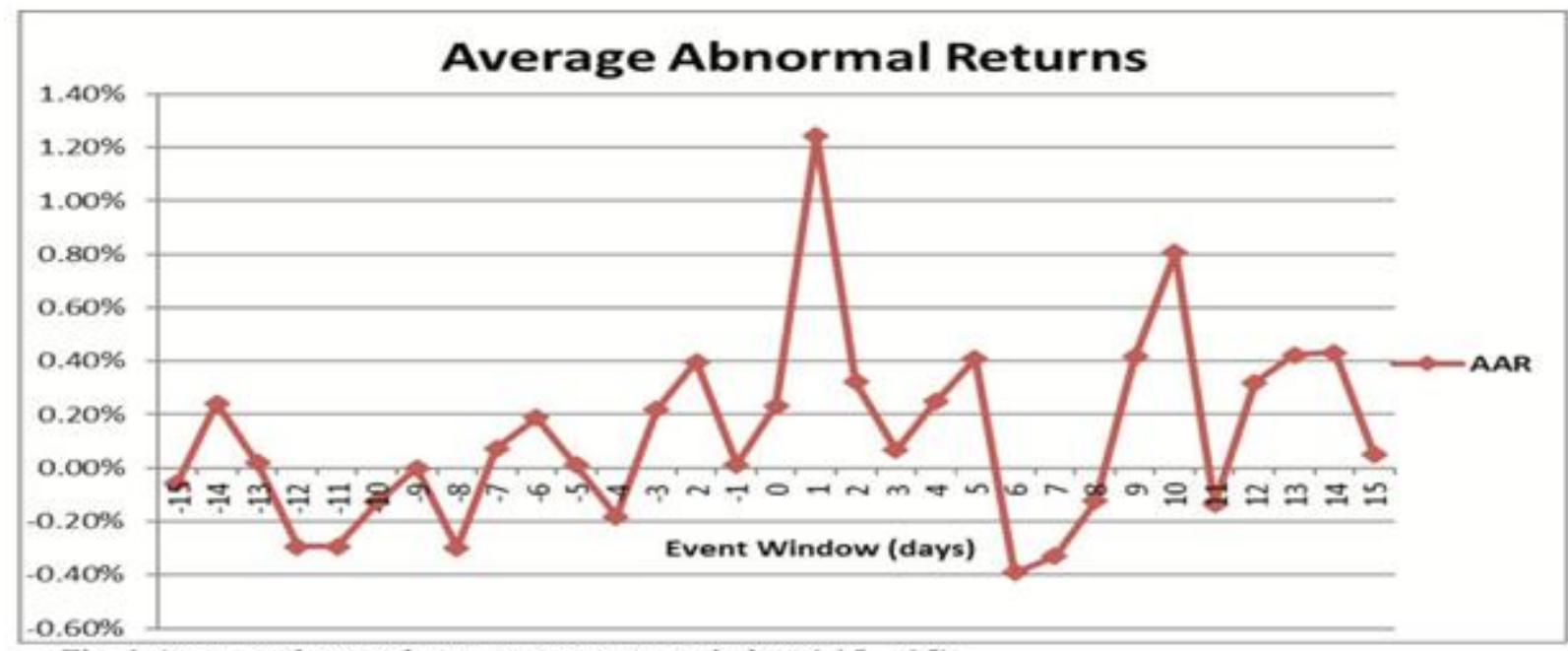

Fig. 1 Average abnormal returns over event window $(-15,+15)$ 


\section{International Journal of Social Science and Economic Research}

ISSN: $2455-8834$

Volume:05, Issue:09 "September 2020"

The plot shown in Fig 1 clearly shows that there is high volatility in stock returns around the elections. The positive returns can be observed 3-4 days before the announcement of the results.

Ch. Balaji, G.D.V. Kusuma, B. Ravi Kumar analyze the effect of general elections on both NSE and $\mathrm{BSE}$ returns in pre-elections and postelections period and to analyze and compare the volatility i.e. variance of daily returns in the stock market for short term (10 days), medium term (20 days) \& long term (30 days) in pre-elections and post- elections period. The analysis is to calculate the average returns, dispersion of price and the impact in the post-election period. For this analysis 5 election sessions were considered that is $1998-2014$. To analyse the data $t$ test, $f$ test is used. The time period of the study has been classified into pre-elections and post elections period.

The daily closing prices of NIFTY \& SENSEX index have been collected from the yahoo finance website for a period from 1998 to 2014 which includes a total of 5 Lok Sabha. The Return is calculated using logarithmic method as follows:

$\mathrm{Rt}=\log (\mathrm{Pt} / \mathrm{Pt}-1)$

$\mathrm{Rt}=$ Market return at the period $\mathrm{t}$

$\mathrm{Pt}=$ Closing Price of index at day $\mathrm{t} \mathrm{P}$

$\mathrm{t}-1=$ Closing Price of index at day $\mathrm{t}-1$

$\log =$ Natural $\log$

The standard deviation and variances during the previous and next 10, 20, and 30 days of the elections is calculated, after this, the statistical tools, a paired T-test using SPSS have been applied on average returns. F-test has been applied over the variability of returns of SENSEX and NIFTY over different periods.

During 30 days the consequence of the combined example t test were not huge, demonstrating that there is a huge increment in the profits from the pre-Election period to the post-Election period. The analysis concluded there is no impact of Election on the returns of long term period in NIFTY and SENSEX. During 20 days The aftereffect of the matched example t test were not noteworthy, showing that there is a huge increment in the profits from the pre-Election period to the post-Election period. The exploration held the invalid theory. There is no significant impact of Election on the returns of medium term period. During 10 days The result of the paired sample $\mathrm{t}$ test were not significant, indicating that there is a significant increase in the returns from the pre-election period to the post-Election period The research retained the null hypothesis. The research concludes there is no significant impact of Election on the returns in short term period of 


\section{International Journal of Social Science and Economic Research}

ISSN: $2455-8834$

Volume:05, Issue:09 "September 2020"

NIFTY. The aftereffects of F-Test on the changes of profits uncover that present moment and medium term period were more unstable than the long haul time frame when contrasted with comparative long haul period before the Election, in only one case, yet principally there is no huge distinction.

It was also seen that the Election has more effect in short term, less in medium term and it diminishes in the long term after the Election announcement. Investors should be cautious in the short term as a speculator by making investment strategies can earn extra profits during this time.

\section{$\underline{\text { POLITICAL INSTABILITY }}$}

Literature provides connection between political instability and stock prices. Barro and Lee (1994) presumed that political instability and monetary development are contrarily related. Any political government come into power in the wake of getting votes from the general population and government arrangements are intended to address the strategies that cook their constituent base Hibbs (1977). In like manner, Beaulieu et. al. (2005) found that stock return unpredictability increments as level of association's presentation towards political hazard increments .

Alesina, et al. (1992) explores the connections between political instability and economic development. They took sample of one hundred and thirteen countries for the period of 1950-82. This study used the simultaneous equations model and tried to measure growth of the economy and political insecurity. This study also used the Amemiya's Generalized Least Square technique (AGLS). It was discovered that whenever chances for government to endure are lower, it would likewise diminish the pace of development for the economy. Correspondingly, if there would be solidness of the Government, there would be higher pace of the development in the economy. Similarly the stock markets and the commodity markets would gain confidence.

Mei and Guo (2002) investigated the effects on financial crises as a result of political unrest. Panel data of emerging markets of twenty-two countries was used for analysis. It was found that out of total nine crises happened in these economies were during the time period of elections and transfer of power from one government to the other. Data was analysed using Probit regression and switching regression analysis. Aftereffects of their investigation presumed that there exists connection among decisions and political instability. It was additionally revealed that advertise unpredictability was high during these timespans. Authors hold a sentiment that institutional financial specialists in the rising economies waver to put resources into the market during the period of successive changes in the administration.

As you can see in the figure given below these countries are the ones that are deemed political instable and the countries who have a financial market in this list have it with limited confidence and volume thus having considerably high volatility by default. 
International Journal of Social Science and Economic Research

ISSN: 2455-8834

Volume:05, Issue:09 "September 2020"

The Political Instability Index shows the level of threat posed to governments by social protest. The index scores are derived by combining measures of economic distress and underlying vulnerability to unrest. The index covers the period 2009/10, and scores are compared with results for 2007.

\begin{tabular}{|c|c|c|c|c|c|c|}
\hline Rank & Country & vulnerability. & distress & score & & score \\
\hline 1 & Zimbabwe & 7.5 & 10.0 & 8.8 & $\Rightarrow$ & 8.8 \\
\hline 2 & Chad & 7.1 & 10.0 & 8.5 & - & 7.5 \\
\hline 3 & Congo (Democratic Republic) & 8.3 & 8.0 & $\mathbf{8 . 2}$ & - & 7.2 \\
\hline 4 & Cambodia & 7.9 & 8.0 & $\mathbf{8 . 0}$ & - & 6.0 \\
\hline 4 & Sudan & 7.9 & 8.0 & 8.0 & - & 7.0 \\
\hline 6 & Iraq & 8.8 & 7.0 & 7.9 & $\Rightarrow$ & 7.9 \\
\hline 7 & Cote d'Ivoire & 7.5 & 8.0 & 7.8 & $\Rightarrow$ & 7.8 \\
\hline 7 & Haiti & 7.5 & 8.0 & 7.8 & - & 6.8 \\
\hline 7 & Pakistan & 7.5 & 8.o & 7.8 & - & 5.8 \\
\hline 7 & Zambia & 7.5 & 8.0 & 7.8 & - & 6.8 \\
\hline 7 & Afghanistan & 7.5 & 8.0 & 7.8 & - & 6.8 \\
\hline 7 & Central African Republic & 7.5 & 8.0 & 7.8 & - & 5.8 \\
\hline 13 & North Korea & 5.4 & 10.0 & 7.7 & - & 3.7 \\
\hline 14 & Bolivia & 8.3 & 7.0 & 7.7 & - & 5.7 \\
\hline 14 & Ecuador & 8.3 & 7.0 & 7.7 & - & 6.7 \\
\hline 16 & Angola & 6.3 & 9.0 & 7.6 & - & 5.6 \\
\hline 16 & Dominican Republic & 6.3 & 9.0 & 7.6 & - & 5.6 \\
\hline 16 & Ukraine & 6.3 & 9.0 & 7.6 & - & 4.6 \\
\hline 19 & Bangladesh & 7.1 & 8.0 & 7.5 & - & 4.5 \\
\hline 19 & Guinea & 7.1 & 8.0 & 7.5 & - & 6.5 \\
\hline 19 & Kenya & 7.1 & 8.0 & 7.5 & - & 6.5 \\
\hline 19 & Moldova & 7.1 & 8.0 & 7.5 & - & 4.5 \\
\hline 19 & Senegal & 7.1 & 8.0 & 7.5 & - & 6.5 \\
\hline 19 & Guinea Bissau & 7.1 & 8.0 & 7.5 & - & 6.5 \\
\hline 19 & Nepal & 7.1 & 8.o & 7.5 & - & 6.5 \\
\hline 19 & Niger & 7.1 & 8.0 & 7.5 & - & 5.5 \\
\hline 27 & Bosnia and Hercegovina & 7.9 & 7.0 & 7.5 & - & 6.5 \\
\hline
\end{tabular}

Source : The Economist

On the other hand ,Gul et al. (2013) proved that political instability does have considerable effect on the stock prices. This study used event study methodology for testing this relationship. His study found that 2008 financial crises time was the time of hardships and difficulties for the equity market investors. Authors further made a feeling that during 2007-10 time, the value showcase confronted challenges in light of happenings of occasions which has diminished outside and residential interest in the market. Stock market didn't perform well in that time what's more these issues different components like fear based oppressor assaults, 9/11 psychological oppressor assault in USA and its eventual outcomes to the remainder of the world, bombings, and death of major political pioneers like the death of Benazir Bhutto, Nawab Akbar Bugti. Political instability was likewise expanded as a result of legal executive and General Mushraf conflicts, aggressor assaults in innate zones and furthermore in Malakand division, rambles assault by the United States and numerous different issues made the circumstance of Pakistani value advertise surprisingly more terrible. Karachi stock exchange 100 index was launched first time in 1997 with a base value of 1000 and it rose to the 1770 points in 2001. In 2005 Karachi stock market 100 Index reached at the level of 9989 points. In the year 2007 it reached to 12285 points and in December of the same year points soared to 14814 points. But on December 26, 2007 assassination of Benazir Bhutto the decline of the stock market 100 Index 


\section{International Journal of Social Science and Economic Research}

ISSN: $2455-8834$

Volume:05, Issue:09 "September 2020"

was not recovered till the end of 2008. However, during this period index gained a high point of 15500 in April, 2008 but till the year of 2008 it was touching its floor.

IRSHAD Hira (2017) through this study aim to explore the relationship between political instability and stock market performance and market volatility. This study will elaborate the collective effect of events like strike, assignations, riots, demonstrations, government change, and government longevity on stock market returns. Similarly, the findings of this study may help regulatory authorities and government. The idea of connection between political instability and stock market gives noteworthy data to settle on venture decisions. Since a long time ago run presence of the stuns in stock prices because of political instability and short run disequilibrium in stock prices creates signals for financial specialists. Stock market right now intermediary for the economy of nation. The information for political instability is gotten to from the main papers and the book "Pakistan 58 years" (Razi and Shakir, 2005). Information for the stock market record is removed from the yahoo money from the year 1998 to 2012. There are number of strategies which may assist with analyzing this relationship. For dissecting since a long time ago run connection between political instability and stock market list ARDL Co-mix have been utilized. Aftereffects of the investigation showed the negative relationship of stock prices with political instability. In addition, consequences of proposed that instable political framework eventually drives decrease in stock prices. Expansion has indicated negative relationship with stock prices while, modern creation and Exports have positive relationship with stock prices.

\section{POLICY ANNOUNCEMENTS BY THE CENTRAL BANKS AND GOVERNMENT} $\underline{\text { OFFICIALS }}$

A growing number of papers in both the economics and finance literatures focuses on the effect of economic news on asset returns. Nonetheless, there seems to exist a wide gap between these two literatures. To start with, while financial experts have tended to focus on the impact of the effect of new data on the degrees of advantage restores, their partners in money have underscored the connection among news and the unpredictability of profits. Second, although the majority of papers in the economics literature have zeroed in on the effects of monetary policy surprises on various asset markets, only a handful of studies in finance have actually focused on the impact of monetary policy news on market volatility and the news-volatility literature has generally not distinguished between anticipated and surprise announcements.

Antulio N. Bomfim (2003)through his paper examine pre-announcement and news effects on the stock market in the context of public disclosure of monetary policy decisions.First, there is the potential for pre-announcement effects, the first leg of a phenomenon that Jones et al. (1998) dubbed the "calm-before-the-storm" effect. Jones et al. find that conditional volatility in the Treasury market tends to be lower in the days leading up to releases of major economic data--the 


\section{International Journal of Social Science and Economic Research}

ISSN: $2455-8834$

Volume:05, Issue:09 "September 2020"

"calming" or pre-announcement effect--and then higher on the day of the announcement itself-the "storm" or news effect. The second channel through which financial strategy choices conceivably influence advertise unpredictability identifies with the idea of the choice itself. This paper argues that the two literatures can learn from one another. From one viewpoint, economic announcements in essence, without controlling for the component of shock in such announcements, may help clarify why such a significant number of studies have neglected to locate a noteworthy connection between advertise volatility and economic news. Then again, by either verifiably accepting that the restrictive volatility of stock returns is time invariant or by just leaving now is the right time varying nature unknown, financial business analysts have neglected to consider a conceivably critical impact of approach amazes on the short-run conduct of the market. (Harris and Raviv, 1993 and Varian, 1989). The exact model is an expansion of crafted by Jones et al. (1998) and Andersen and Bollerslev (1997, 1998). All information is day by day and run from June 1989 to December 1998. All data are daily and run from June 1989 to December 1998. The paper also looks at how the actual interest rate decisions of policy makers affect stock market volatility. The element of surprise in such decisions tends to boost stock market volatility significantly in the short run, and positive surprises higher-than expected values of the target federal funds rate tend to have a larger effect on volatility than negative surprises.

Reint Gropp, Arjan Kadareja (2012) investigate that if the public information available is stale, we should observe a larger spike in volatility, if volatility is driven by traders with different private information or beliefs. The paper contends that more excellent, timelier, open data decreases banks opacity and results in a closer arrangement of data sets of dealers, leaving less space for private data or convictions to drive volatility. The more recent the publication of the annual report, the smaller the disagreement of traders as to the implications of the shock for the future profitability of the bank and the smaller the uncertainty of investors regarding the bank's value. The paper also hypothesize and test an inverse relation between the persistence of volatility and the quality of the publicly available information. Obviously, these contentions possibly apply if yearly reports of banks in actuality pass on any helpful data to business sectors. Right now, approach is a joint trial of the nearness of private data and the estimation of bank yearly reports to business sectors. They utilize unanticipated money related arrangement choices in the euro territory and the UK as their stun variable. The example time frame, which is dictated by the accessibility of tick information (see beneath), is from (January 1999 until May 2) . The proof gave that stale open data (more established yearly and between time reports) essentially increase volatility for an unanticipated financial strategy stun.

The outcomes recommend that (i) unanticipated monetary policy shocks bring about a significant transient increment in bank stock volatility yet foreseen monetary policy shocks don't; (ii) the 


\section{International Journal of Social Science and Economic Research}

ISSN: 2455-8834

Volume:05, Issue:09 "September 2020"

expansion in volatility is essentially higher on account of banks, for which freely accessible data is stale; (iii) the expansion in volatility is fundamentally progressively diligent on account of banks, for which the openly accessible data is stale, despite the fact that this impact is financially little; (iv) bid-ask spreads and volatility are higher before monetary policy announcements if information is stale.The results support theories proposed by Harris and Raviv and Shalen (1993).

Nikolay Gospodinov, Ibrahim Jamali investigate the dynamic response of stock exchange volatility to changes in monetary policy. Using a vector autoregressive model, findings reveal a big and asymmetric response of stock returns and volatility to monetary policy shocks. Although the rise within the volatility risk premium, futures-trading volume, and leverage appear to contribute to a short-term increase in volatility, the longer-term dynamics of volatility are dominated by monetary policy's effect on fundamentals. The estimation results from a bivariate VAR-GARCH model suggest that the Fed doesn't answer the stock exchange at a high frequency, but they also suggest that market participants' uncertainty regarding the monetary stance affects stock exchange volatility.

\section{CURRENCY DEPENDENCE AND POLITICS}

Volatility is also present in currency markets around the world aswell. Hence, the effect of the exchange rate on stock index returns has been studied in several works, namely Solnik, (1984) who proposed that, in the long-run, the stock market and the foreign exchange market are separated, since no proof can be found showing that these two variables are related. this study has been proven later on in part of Sahadudheen (2013) study who examines the effect of volatility in both rupee-dollar and rupee-euro exchange rates on stock prices in India using daily data from 3/04/2007-31/03/2012 adopting a generalized autoregressive conditional heteroskedasticity (GARCH) developed in 1982 by Robert F. Engle's study suggests a negative relationship between exchange rate and stock prices in India.

K. Kennedy, F. Nourizad This paper investigates empirically the effect of volatility of the rate of exchange of the U.S. dollar and the euro on U.S. stock exchange volatility while controlling for variety of drivers of stock return volatility. Employing a $\operatorname{GARCH}(1,1)$ model and using weekly data covering the amount from the week of January 1, 1999 through the week of January(2010), it's found that the 9/11 surprise attack, bear markets, fluctuations in jobless claims, and negative equity market returns increase financial volatility. Finally, it's found that when major drivers of monetary volatility are controlled for, increased rate of exchange volatility exerts a positive and statistically significant effect on the volatility of stock returns. Monetary policymakers got to take this effect under consideration when formulating rate of exchange actions within the prevailing managed float. 
Sudarsana Sahoo, Harendra Behera and Pushpa Trivedi This paper investigates the price and volatility spillovers between the Indian foreign exchange (forex) and stock markets over the sample period April 4, 2005 to March 31, 2017 using bivariate asymmetric BEKK- GARCH $(1,1)$ model. The paper considers 5 sub periods with two extremely volatile periods. The empirical results establish unidirectional price spillovers from the stock market to the foreign exchange market during the full sample period. The volatility overflows between the two markets are discovered uniquely during the two sub-test periods with extremely high exchange rate volatility, i.e., bidirectional overflows during the subsequent sub-test period and unidirectional overflows from the securities exchange to the forex market during the fourth sub-test period. The reaction of the foreign exchange market to volatility overflows from securities exchanges is deviated, i.e., negative shocks from the financial exchanges brought about higher volatility in the forex market versus the positive stuns. The proof on volatility overflows during profoundly unstable periods shows 'contagion' impact that intensifies the volatility and compounds the worry in the monetary framework. The volatility spillovers were found to be more of a specific phenomenon, observed mainly during the periods of high exchange rate volatility. The volatility spillovers from stock markets to the forex market were evident during the 2nd and 4th sub-sample periods, while that from the forex market to stock market was observed mainly during the 2 nd sub-sample period .

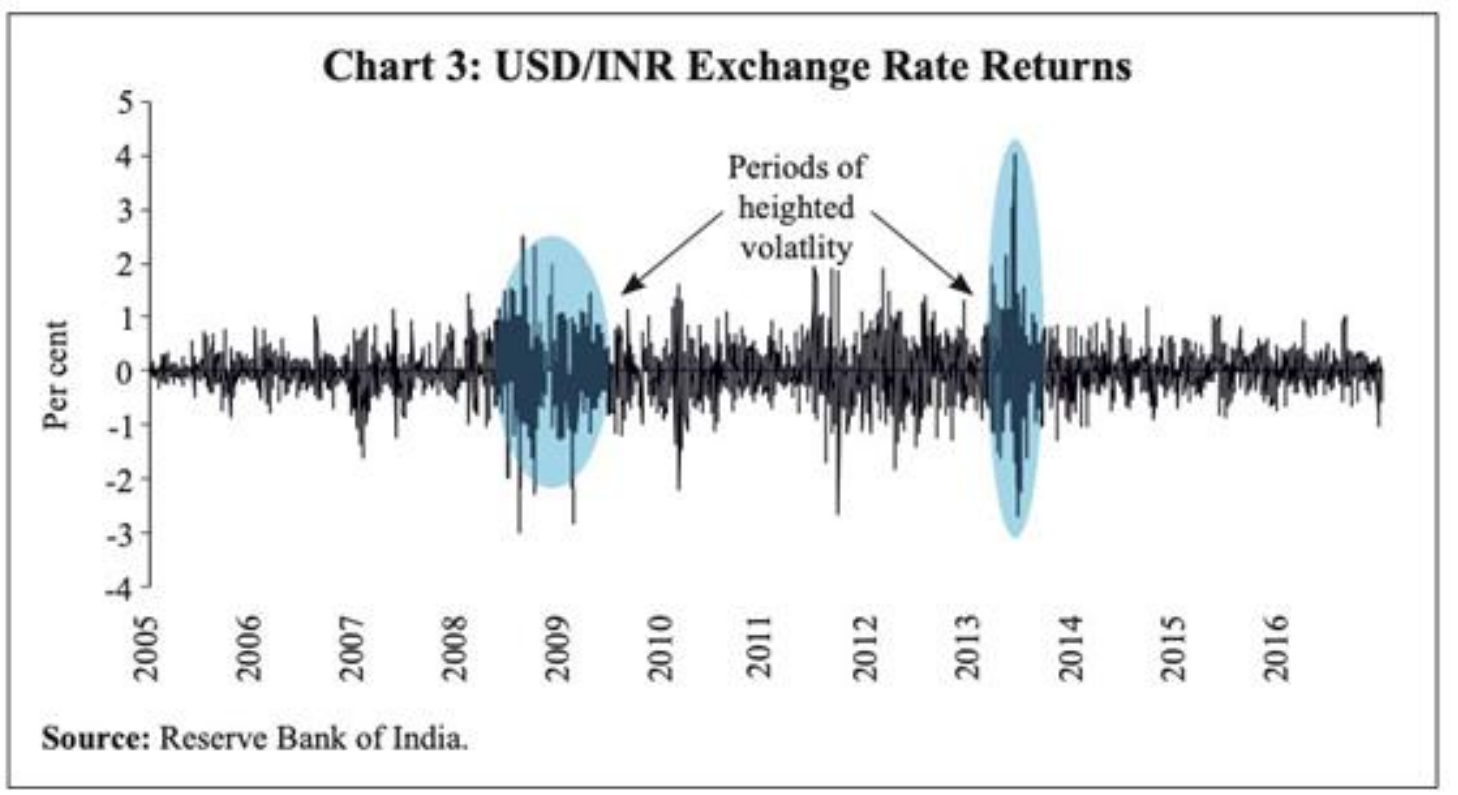


International Journal of Social Science and Economic Research

ISSN: 2455-8834

Volume:05, Issue:09 "September 2020"

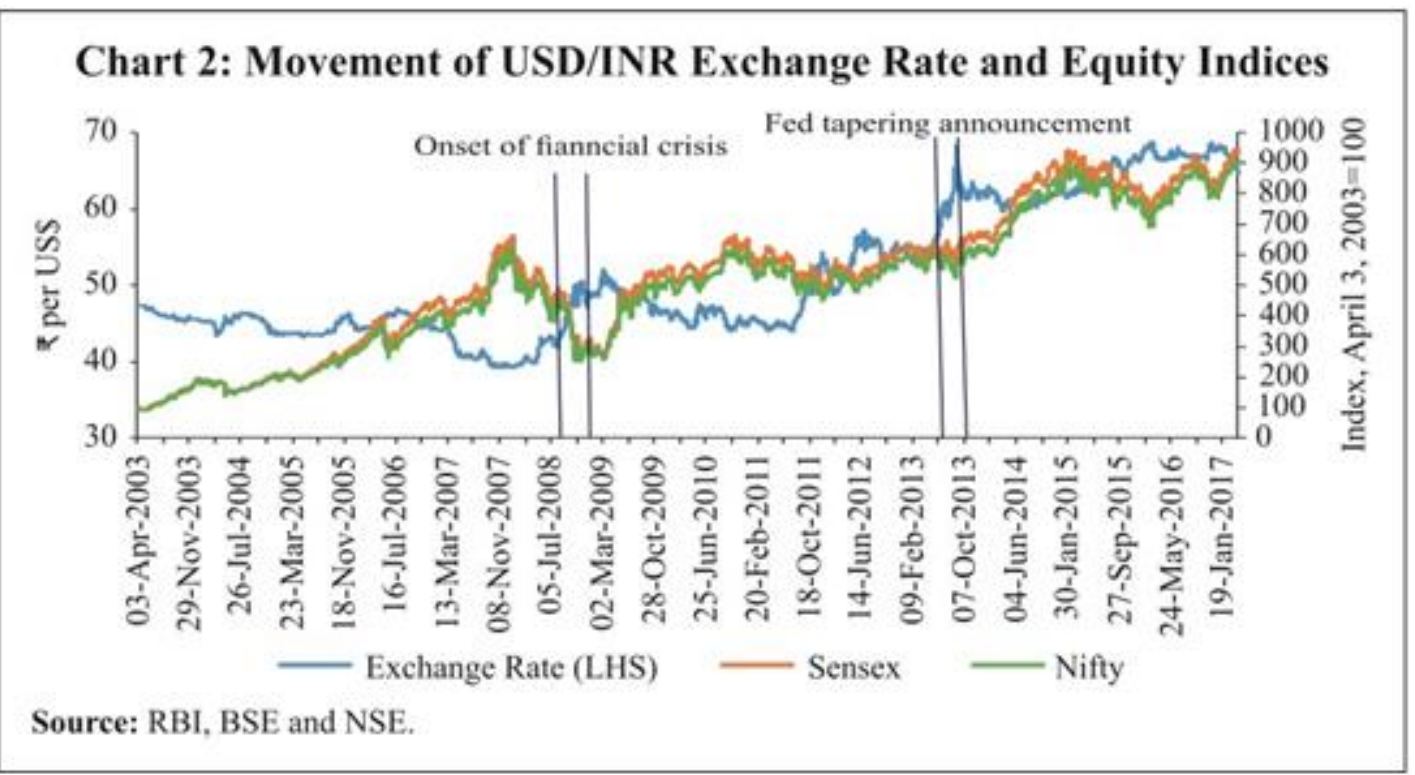

Calendar Effect Market Anomalies

In financial markets, anomalies refer to circumstances when a security or gathering of protections performs in opposition to the thought of effective markets, where security costs are said to mirror all accessible data anytime. With the consistent discharge and quick dispersal of new data, once in a while effective markets are difficult to accomplish and much progressively hard to keep up. There are many market anomalies; some occur once and disappear, while others are continuously observed. In the context of the India, an evolving market considering its developing status, there is a lot of scope for the presence of such anomalies and the papers discussed below provide an insight on the available literature.

Patel(2008) observes that emerging stock markets are viewed as fundamentally different from the markets of developed nations, and data from emerging stock markets are examined relatively less frequently than those of developed stock markets. At the same time conclusion drawn from the available data might not suffice for the purpose of drawing clear conclusions considering developing markets are always in transition. Evidence of monthly seasonality in the Indian stock market is somewhat mixed which could be attributed to the fact that considering its developing status, it is still in its evolving phase.

For the purpose of testing, the author collected values from the BSE 500 and the NSE 500 indices for the last trading day of each month. Data for last trading day of the month for each index were available from June 1999 to June 2007, hence making ninety-six monthly return observations available, i.e. from July 1999 to June 2007 for each index. 


\section{International Journal of Social Science and Economic Research}

ISSN: $2455-8834$

Volume:05, Issue:09 "September 2020"

Also, for the Mar-to-May effect, it is possible that mean returns for Mar-to-May are lower than those for the remaining nine months because of the Nov-Dec effect. For the BSE500 index, the paper observes that November and December generate substantially greater returns than those for almost all other months. High positive returns were also generated during August, but the months of September and October have negative returns. The paper therefore concluded that an investor should invest in the Indian stock market during the months of November and December. A similar pattern is presented for the second index, the NSE 500. Greater mean returns are generated during November and December than during the other ten months of the year. The author hence concludes by theorizing that the Nov-Dec effect is related to the Hindu festival of Diwali, which is generally celebrated in late October or early November. On the other hand, the Mar-to-May effect may be a consequence of the fact that the Indian national budget is announced during the month of February, and the tax year in India ends in March

Muhammad Ali Nasir, Matteo Rossi study attempts to research the impacts of schedule irregularities (Ramadan impact), a regular example in the Pakistani Stock market. It is accepted that the heavenly month of Ramadan is anticipated to impact the conduct of the Karachi Stock Exchange (KSE) since the environment in the country during Ramadan is different compared to other months since people dedicate more time to execute religious rituals, hence slows down the general economic activity. Past authors who have completed their investigation on the comparable measurements, for example, Hussain (1998) which revealed huge decrease in stock returns volatility during Ramadan and no noteworthy change in the mean return, while Seyyed et al. (2005) indicated declined exchanging volume and returns and Almudhaf (2012) examination of 12 markets demonstrated heterogeneous reaction of financial exchanges in various nations during Ramadan. The perception depends on every day frequencies for an entire decade. The information right now the day by day KSE 100 list focuses for a long time running from first of January 2001 to 31st of December 2010 all chose from the essential stock market in Pakistan, the KSE. The impacts of Ramadan are inspected through GARCH and standard least square (OLS) models individually. The examination reaches two inferences with the main demonstrating that the Ramadan has a minor positive effect on the securities exchange and the subsequent end expresses that the financial exchange shows less volatile behaviour during the holy month of Ramadan.

\section{CONCLUSION}

Volatility is nothing but a behvaioural change brought by investors as their perception of market keeps changing second by second due to various reasons other than the ones documented in the above Litreature review. All over the world stock markets function in a similar manner but it's the investors with unknown rationality which decide the fate of the market indexes. Such wholesome changes in oil prices, political instability form the essescence of world supply chain irrespective of which country is involved. A attack on Saudi Aramco's oil plant caused a huge 
International Journal of Social Science and Economic Research

ISSN: 2455-8834

Volume:05, Issue:09 "September 2020"

swing in oil prices as it involved both political tension and oil supply problems although it immediately got back.

When United States of America announced and carried out the assasination of Iranian leader Qasem Soleimani it did get a lot of tension for a few days in The United states as Iran could plan to attack back. The flip side to Volatility is that usually these effects only last for few days or even hours during the event happeneing or while the event is anticipated. Since more and more "traders" come in the market price movements have gotten faster hence in situations when volumes are less the volatility is deemded to be high. Dollar can be termed as USAs soft power. A rise is Dollar for example would effect Indias budgetary requirements and thus would also increase the import bill and automatically increasing oil prices domestically. Such integrations is the reason why Arbitragers cause volatility spillovers although in the short-run .

\section{RESEARCH GAP}

Although a lot is cleared out with the following litreature review something which was missing or rather could be researched more would be a volatility model that integrate all sorts of price moments and political shifts and carry out a significant study to determine a real volatility number for future researches in short term investing.

\section{REFRENCES}

Alesina, A., Özler, S., Roubini, N., \& Swagel, P. (1992). Political instability and economic growth. Journal of Economic Growth, 1, 189-211.

Bomfim, A.N. (2003). Pre-announcement effects, news effects, and volatility: Monetary policy and the stock market.

Ch. Balaji, G.D.V. Kusuma, B. Ravi Kumar,.” Impact of General Elections on Stock Markets in India". (2018). Open Journal of Economics and Commerce, 1(2), pp.1-7.

Degiannakis, S., Filis, G.N., \& Kizys, R. (2014). The effects of oil price shocks on stock market volatility:evidence from European data.

Gokmenoglu, K.K., \& Fazlollahi, N. (2015). The Interactions among Gold, Oil, and Stock Market: Evidence from S\&P500.

Gomes, M., \& Chaibi, A. (2014). Volatility Spillovers Between Oil Prices And Stock Returns: A Focus On Frontier Markets.

Gospodinov, N., \& Jamali, I. (2015). The Response of Stock Market Volatility to Futures- 
International Journal of Social Science and Economic Research

ISSN: 2455-8834

Volume:05, Issue:09 "September 2020"

Based Measures of Monetary Policy Shocks.

Gropp, R.E., \& Kadareja, A. (2012). Stale Information, Shocks, and Volatility.

Gul S., Khan M. T., Saif N., Rehman S., Roohullah (2013) "Stock Market Reaction to Political Events (Evidence from Pakistan)", Journal of Economics and Sustainable Development, Vol.4, No.1, 2013

Iqbal, S., Iqbal, N., \& Muneer, A. (2019). Islamic Calendar Anomalies Reshaping Investor Behavior: A Qualitative Study.

Irshad, H. (2017). Relationship Among Political Instability, Stock Market Returns and Stock Market Volatility. Studies in Business and Economics, 12, 70 - 99.

Kennedy, K., \& Nourzad, F. (2016). Exchange rate volatility and its effect on stock market volatility.

Kumar Deva B. , Sophia Sharon and Jucunda Evelyn Maria (2015). Empirical Study on Effects of the Lok Sabha Election on Stock Market Performance (BSE SENSEX), Research Journal of Management Sciences. Vol. 4(2), 1-9, February.

Mei, J., \& Guo, L. (2002). Political Uncertainty, Financial Crisis and Market Volatility.

Patel, J. b. (2008). calendar effects in the indian stock market. International business \& Economic research journal.

Sahoo, S., Behera, H.K., \& Trivedi, P. (2019). Return and volatility spillovers between currency and bond markets in India.

Savita, A. R. (2015). Return Volatility around National Election: Evidence from India.

Procedia- Social and Behavioural Sciences 189, 163-168. 